\title{
Horticultural markets promote alien species invasions: an Estonian case study of herbaceous perennials
}

\author{
Merle Ööpik', Robert G.H. Bunce', Monika Tischler' \\ I Institute of Agricultural and Environmental Sciences, Estonian University of Life Sciences, Kreutzwaldi 5 , \\ 51014 Tartu, Estonia \\ Corresponding author: Merle Ö̈pik (merle.oopik@emu.ee)
}

Academic editor: I. Kühn | Received 30 October 2012 | Accepted 29 April 2013 | Published 28 June 2013

Citation: Ööpik M, Bunce RGH, Tischler M (2013) Horticultural markets promote alien species invasions: an Estonian case study of herbaceous perennials. NeoBiota 17: 19-37. doi: 10.3897/neobiota.17.4217

\begin{abstract}
Gardening is a popular pastime, but commercial horticulture is responsible for the introduction of alien species and contributes to invasions in a variety of ways. Although an extensive international literature is available on plant invasions, it is still important at the national level to examine the influence of local factors. Accordingly, 17 nurseries in Estonia that cultivated and sold perennial alien species were selected, and a list of species and prices was compiled. The relationships between species status, and factors such as their abundance in the wild were examined statistically. A qualitative list of the nationally problematic species among herbaceous perennials was also completed. A total of 880 taxa were recorded, of which $10.3 \%$ were native and $89.7 \%$ alien. In all, $87.3 \%$ of the alien species were still confined to cultivated areas. The ecological and socio-economic characteristics of the taxa were described, and lists of the families of casual, naturalised and invasive aliens were provided. Both native and increasing wild alien species have a very similar profile on the market. Alien species that are less expensive, widely available and have more cultivars per species on the market are also more likely to escape. The invasive status and abundance of escaped aliens in an area increases with residence time. In general, socio-economic factors create new and reflect previous propagule pressures from commercial horticulture, which continuously increase the likelihood of alien species surviving and invading new areas. Our findings suggest that these national socioeconomic market-related factors explain much of the invasiveness of various perennial ornamental species, and therefore regional and national authorities urgently need to regulate and control the ornamental plant trade to diminish the risk of new invasions.
\end{abstract}

\section{Keywords}

Perennial alien species, commercial horticulture, human-mediated propagule pressure, residence time, legislation and regulation

Copyright Merle Ö̈pik et al. This is an open access article distributed under the terms of the Creative Commons Attribution License 3.0 (CC-BY), which permits unrestricted use, distribution, and reproduction in any medium, provided the original author and source are credited. 


\section{Introduction}

Biological and human-mediated mechanisms in invasions of alien plant species are interdependent, and as a result, it is difficult to predict where and why such invasions will occur. However, most plant naturalisations and invaders nowadays originate from and in the future will derive from deliberate importations (Mack and Erneberg 2002, Kowarik 2003, Mack 2003). Specifically, the study of the economic uses of plant species that are invasive in various parts of the world has established that most plant invaders are ornamentals (Weber 2003). These species have been introduced for horticultural use by nurseries, botanical gardens, and individuals (Reichard and White 2001). Of course, invasive alien species can be introduced unintentionally (Pyšek et al. 2011) or by other deliberate pathways developed by humans, e.g., for forestry and agricultural purposes (Mack and Lonsdale 2001, Starfinger et al. 2003). Nevertheless, the expansion and globalisation of the horticultural trade is widely accepted as a principal reason for the increase in alien species (e.g., Dehnen-Schmutz et al. 2007a, 2007b, 2010, Barbier et al. 2011) and it is also widely recognised that many invasions begin in urban domestic gardens (e.g., Smith et al. 2006, Hanspach et al. 2008). On a general macroeconomic scale, income growth is the primary driver of globalisation and there is a clear association between Gross Domestic Product and the richness of alien floras (Hulme 2009). In addition, when the variations in invasion rates were partitioned according to a range of explanatory variables, it was found that only national wealth and population density were statistically significant (Pyšek et al. 2010). These predictors simply reflect the intensity of human activities, in which the horticultural trade is also a relevant component.

There is now an extensive literature that analyses the reasons why certain species become invasive (e.g., Pyšek and Richardson 2007, Küster et al. 2008, Milbau and Stout 2008). Many papers identify particular traits that cause an ornamental alien species to become invasive. For example, Marco et al. (2010) showed that when an ornamental perennial alien species escapes from cultivation, pre-adaptation to the local environment and its potential for spreading vegetatively play important roles, along with gardening practices. Most authors conclude that successful invasion cannot be explained by a single trait or characteristic, but is determined in combination with climatic and environmental factors, species traits, and human uses (Thuiller et al. 2006, Milbau and Stout 2008, Beans et al. 2012, Richardson and Pyšek 2012). The phrase "human-mediated propagule pressure" is often used to explain processes, where propagule pressure is defined as the frequency with which a species is introduced to a site, combined with the number of individuals in each introduction event (Simberloff 2009; see also arguments in Lockwood et al. 2009). Human-mediation multiplies this process and it is connected both to human population size and density and to economic characteristics (Pyšek et al. 2010, Trueman et al. 2010). Species residence time gives another dimension to the propagule pressure: the longer the species is present in an area, the more propagules are spread and the probability of establishing new populations increases (Rejmánek et al. 2005, Milbau and Stout 2008, Trueman et al. 2010, etc.). 
Human-mediated propagule pressure from ornamental horticulture itself plays both a direct and implicit role for species to become naturalised and even invasive. At a local level it is particularly important, because it promotes invasions in variety of ways (see, e.g. Reichard 2011): 1) the introduction and reintroduction of new plants; 2) the selection of species and cultivars for characteristics such as climatic suitability and rapid propagation; and 3) the creation of propagules due to long residence time, the pressure of gardening fashions and the great number of garden centres. In Britain, market presence, prices and dates of introduction are among the socio-economic factors that have influenced invasions (Dehnen-Schmutz et al. 2007a). Pemberton and Liu (2009) have also stressed the importance to successful naturalisation of the number of years a plant was sold. The current naturalisation success of North American woody species in Europe is determined by introduction history and particularly by planting frequency (Bucharova and van Kleunen 2009). Selective introduction and human-mediated selection of ornamental plants with fast and abundant germination might increase the risk of species ultimately becoming invasive (Chrobock et al. 2011). Kowarik (2003) suggested that secondary releases of alien species might mimic demographic and dispersal processes that influence population growth and expansion of range, and provide opportunities to species whose propagules are not able to move naturally over long distances. In addition, cultivation (e.g., protection from predators and parasites, drought, cold) can facilitate naturalisation by protecting alien populations from environmental stochasticity (Mack 2000).

It has previously been shown that in the case of the Estonian Alien Flora (Ö̈pik et al. 2008), the establishment and naturalisation of alien species in a given area depended on the level and type of human mediation. The majority (74\%) of 232 naturalised alien species in Estonia originates from deliberate introductions. Overall, approximately half of the alien flora consists of short-lived species, but only $24 \%$ of the naturalised species belong to this group. Moreover, cultivation in a cold temperate region has tended to favour perennial species with propagative advantages for attaining greater abundance and higher invasive status; especially in natural and semi-natural habitats. The pattern of invasive species is more diverse, but among the most problematic species there are also deliberately introduced perennials, which have escaped from cultivation and are now spreading aggressively, forming monocultures, are toxic, and causing other conservation or human health problems. Hence, through selection and cultivation, humans increase propagule pressure, while invasion success also increases with alien species' residence time. Consequently, at a national level in countries such as Estonia, it is necessary to examine the influence of local factors more deeply, so that measures can be taken to reduce the probability of invasions.

In this paper, the following questions are raised in order to examine the situation in Estonia in further detail:

(i) What is the number of herbaceous perennial species offered for sale, both to horticultural professionals and amateurs? What is the composition of these species? 
(ii) Is availability (i.e., lower prices at certain outlets) related to the current status of these species, i.e., the presence of the alien species in the spontaneous flora and/ or their abundance in the wild, and how is this connected to species' residence time in Estonia?

(iii) Does this list include problematic or even legally prohibited alien species that may cause nature conservation problems and therefore needs national attention?

\section{Material}

\section{Background information about Estonia}

Estonia lies approximately between latitude $58^{\circ}-60^{\circ} \mathrm{N}$ and longitude $22^{\circ}-28^{\circ} \mathrm{E}$. According to the Estonian Information System's Authority (2012), the total area of Estonia is $45,227 \mathrm{~km}^{2}$, including $42,692 \mathrm{~km}^{2}$ of land. More than one-half of the land area is forest, and one-third is agricultural land (arable land and natural grasslands). Approximately $8 \%$ is urban and infrastructure and the rest of the land is heathland, mires and bogs. Since 31 December 2010, 18.1\% of Estonia has been under various types of nature protection (Environmental Information 2012).

By the end of 2011, the population of Estonia was 1.32 million and had decreased because of migration (Statistics Estonia 2012). Approximately 69\% of the population live in the major towns and cities and $35 \%$ of all live in semi-detached or detached houses, which traditionally have gardens. In 2010, the population density was 30.9 inhabitants per $\mathrm{km}^{2}$. After 1 January 2011, the currency of Estonia was converted to the Euro, but during the research period for the present study the currency was the Estonian kroons (1 EUR = 15.6 EEK).

As mentioned above, national wealth is a key parameter in determining the likelihood of plant invasions. In 2011, the Gross Domestic Product per capita of Estonia was 20.2 US Dollars compared with 15.4 for Latvia and 38.3 for Finland. Estonia is, therefore, not in the highest wealth category, but it is still rich compared with countries outside Europe. However, the economy is growing, and gardening is a very popular activity, especially in the countryside where most houses have gardens. There is, therefore, a strong market for horticultural products.

In Estonia, horticulture, vegetable and fruit production have been concentrated in a relatively small number of businesses: approximately $2 \%$ of the total number of agricultural companies. There are no exact data on the numbers of nurseries in Estonia specialising in ornamental horticulture. The non-profit Estonian Horticultural Association (www.aiandusliit.ee) brings together companies that produce horticultural products for the market, as well as training and science institutions and companies retailing gardening accessories. There are about 80 members and from their occupational description it is estimated that approximately 25-30 of them are linked to the importation, cultivation on-site, and sale of herbaceous perennial species. 


\section{National regulations on (invasive) alien species}

In Estonia, the principal authority on alien species is the Ministry of Environment, which is responsible for legislation and cooperation with international expert groups (e.g., NOBANIS, the Bern convention IAS group, and the EPPO IAS group). The Environmental Board is responsible for nature conservation activities and practical work with alien and invasive alien species.

The Nature Conservation Act (The State Gazette I, 2004, 38, 258) is the principal instrument that forbids the release of alien species into the wild. This Act has resulted in the definition of The List of Invasive Alien Species (Annex of The State Gazette $2004,134,2076)$. This regulation includes both well-established species and plants that are not yet established but which have caused problems in countries with similar environments. At present, this list includes 13 plant species. The import of live specimens and all transactions with live plants are prohibited for all these species.

The complete list of the texts on invasive species that have been implemented to date; including both those that are legally binding and those that are not; is presented in a report entitled "A Comparative Assessment of Existing Policies on Invasive Species in the EU Member States and in Selected OECD Countries" (European Commission 2011).

\section{Methods}

\section{Sample of nurseries, database characteristics, statistical analysis}

Seventeen nurseries located throughout Estonia were selected for this study. The choice was determined by the availability of catalogues. Firstly, an extensive list of cultivars and prices of herbaceous perennial species was compiled from catalogues, and the data was structured at the species, subspecies, and varietal or hybrid taxonomic level. In addition, basic information was collected for each taxon (Table 1), whenever such information was available. The species status in the Estonian Flora was determined from the Vascular Plant Flora of Estonia (Kukk 1999), where natives and archaeophytes are considered to be in the same group, i.e., natives. Hence, the alien species considered in this study were neophytes from this region. The alien species status (casual, naturalised and invasive) and other characteristics connected to alien species' invasiveness on Estonian territory were used as applied in Estonian Alien Flora (Ööpik et al. 2008), after which the invasive status of alien species was used in the sense proposed by Richardson et al. (2000) and Pyšek et al. (2004).

The complete description of species characteristics (Table 1) provides the basis for analysing the relationships between species status (native or alien: non-escaping, casual, naturalised, invasive), abundance in the wild, year of the first introduction (not available for non-escaping aliens), origin area of alien species (Kukk 1999), wholesale or retail price in 2010 (divided into ranges), and the number of nurseries in which the 
Table I. The content of the database of herbaceous perennial species available in the Estonian horticultural market describing the species characteristics and categories assigned to each individual species.

\begin{tabular}{|c|c|c|}
\hline Topic & Characteristic & Categories used \\
\hline $\begin{array}{l}\text { Species identity and } \\
\text { taxonomic position }\end{array}$ & $\begin{array}{l}\text { Genus, species, subspecies, } \\
\text { family }\end{array}$ & \\
\hline $\begin{array}{c}\text { Species status in Estonian } \\
\text { Flora }\end{array}$ & & $\begin{array}{l}\text { Native (1) } \\
\text { Alien (2) }\end{array}$ \\
\hline \multirow[t]{7}{*}{$\begin{array}{l}\text { Alien species invasiveness on } \\
\text { Estonian territory and in the } \\
\text { neighbouring countries }\end{array}$} & Invasive status & $\begin{array}{l}\text { Non-escaping (1) } \\
\text { Casual (2) } \\
\text { Naturalised (3) } \\
\text { Invasive (4) }\end{array}$ \\
\hline & Year of introduction & \\
\hline & Year of the first record in the wild & \\
\hline & $\begin{array}{l}\text { Abundance in the wild } \\
\text { (frequency classes) }\end{array}$ & $\begin{array}{c}\text { Rare (1) } \\
\text { Uncommon (2) } \\
\text { Scattered or occasional (3) } \\
\text { Common (4) }\end{array}$ \\
\hline & $\begin{array}{l}\text { Invasiveness in NOBANIS } \\
\text { (qualitative characteristic) }\end{array}$ & $\begin{array}{l}\text { Potentially invasive or invasive in the } \\
\text { region } \dagger\end{array}$ \\
\hline & $\begin{array}{l}\text { Invasiveness in NOBANIS } \\
\text { (quantitative characteristic) }\end{array}$ & $\begin{array}{l}\text { 0- not mentioned as potentially invasive } \\
\text { or invasive; } 1 \text { - potentially invasive or } \\
\text { invasive in one country. Values of } 2 \text { or } \\
\text { greater denote the number of countries in } \\
\text { which the species is potentially invasive or } \\
\text { invasive. }\end{array}$ \\
\hline & Area of origin (floristic element) & $\begin{array}{c}\text { America, Asia, Europa, Eurasia } \\
\text { (continental), Euro-Siberia, Circumpolar, } \\
\text { Africa, Origin unknown (known only } \\
\text { from cultivation) }\end{array}$ \\
\hline \multirow[t]{4}{*}{ Nursery information $(\mathrm{N}=17)$} & $\begin{array}{l}\text { Species present on the list of a } \\
\text { certain nursery }\end{array}$ & 0 - not present; 1 - present \\
\hline & $\begin{array}{l}\text { Number of nurseries in which } \\
\text { the species is available }\end{array}$ & \\
\hline & $\begin{array}{c}\text { Number of cultivars per species } \\
\text { available }\end{array}$ & \\
\hline & $\begin{array}{l}\text { Wholesale or retail price in } \\
2010 \text { (divided into ranges) }\end{array}$ & $\begin{array}{c}1 \text { class up to } 30 \text { EEK (approx. } 2 \text { EUR) } \\
2 \text { class } 31-50 \text { EEK (> } 2 \text { to } 3.2 \text { EUR) } \\
3 \text { class } 51-100 \text { EEK (> } 3.2 \text { to } 6.4 \text { EUR) } \\
4 \text { class greater than } 100 \text { EEK ( }>6.4 \text { EUR) }\end{array}$ \\
\hline
\end{tabular}

$\dagger$ Latvia, Lithuania, Finland, Sweden, Denmark, Norway, Poland, European part of Russia

species is available. Only one, and in the case of differences between nurseries, the highest price range category for each species was determined. The status of species in neighbouring countries was derived from the database of the European Network on Invasive Alien Species (NOBANIS, www.nobanis.org). In this database, invasive alien species are defined as those whose introduction and/or spread threaten biological diversity.

The STATISTICA software system ver. 11 (StatSoft, Inc. 2012) was used for all statistical analysis to perform a nonparametric Kruskal-Wallis ANOVA ( $H$ statistic), 
an analysis of variance performed on ranks. Specifically, the different characteristics of multiple independent samples (groups) were compared. Species status was related to species price and to availability as well as alien species status, and abundance class to residence time. In addition, the multiple comparisons test was used to assess the mean ranks of all pairs of groups (see Siegel and Castellan 1988) and to compute post hoc measures of the mean ranks of all pairs of groups based on the $z$ statistic. The correlation between price and availability, introduction time, and invasiveness in neighbour countries, was tested with nonparametric Spearman rank correlation $(R)$.

\section{List of species needing attention}

As a practical application, a qualitative list of the nationally problematic species among the herbaceous perennials found in horticultural catalogues was compiled, based on data from local sources (Kukk 1999, Ööpik et al. 2008) and neighbouring countries (NOBANIS database) and on categories of multiple response characteristics as follows:

(i) Invasive or naturalised in Estonia and invasive or potentially invasive in at least three neighbouring countries.

(ii) Naturalised in Estonia and invasive or potentially invasive in two neighbouring countries.

(iii) Naturalised in Estonia.

(iv) Casual in Estonia, but invasive or potentially invasive elsewhere. These species are not addressed in this study.

The complete list of perennials in The List of Invasive Alien Species (The State Gazette Supplement 2004, 134, 2076) was also examined, to analyse whether the current legally valid list is applicable to everyday trade.

\section{Results}

\section{General structure of the database}

The database consists of 3,697 primary entries. These entries were analysed at the taxonomic level of species ( $N=779,89 \%$ of all entries), subspecies $(N=31)$, and variety or hybrid $(N=70)$ to produce a list of 880 taxa (hereinafter called species). Of this list, $10.3 \%$ (91) are native species, 89.7\% (789) alien species. Of all the aliens, 100 have been recorded outside cultivated areas and have reached a certain invasive status in Estonia - 62 are casuals, 35 naturalised, and 3 invasive species: Lupinus polyphyllus Lindl., Saponaria officinalis L. and Solidago canadensis L.. A total of 689 (87.3\% of all aliens) are non-escaping species that are still confined to cultivated land. In all, the species belong to 73 families (Table 2) and 269 genera. The native species in the list are most 
Table 2. The invasive status of perennial species available in the Estonian horticultural market, listed by family.

\begin{tabular}{c|c|c|c|c|c|c}
\hline Family & $\begin{array}{c}\text { Native } \\
\text { species }\end{array}$ & $\begin{array}{c}\text { Non-escaping } \\
\text { aliens }\end{array}$ & $\begin{array}{c}\text { Casual } \\
\text { aliens }\end{array}$ & $\begin{array}{c}\text { Naturalised } \\
\text { aliens }\end{array}$ & $\begin{array}{c}\text { Invasive } \\
\text { aliens }\end{array}$ & All \\
\hline Asteraceae & 10 & 98 & 16 & 8 & 1 & 133 \\
\hline Ranunculaceae & 7 & 58 & 0 & 3 & 0 & 68 \\
\hline Lamiaceae & 8 & 42 & 12 & 3 & 0 & 65 \\
\hline Caryophyllaceae & 9 & 38 & 6 & 2 & 1 & 56 \\
\hline Rosaceae & 8 & 36 & 3 & 3 & 0 & 50 \\
\hline Saxifragaceae & 2 & 45 & 2 & 0 & 0 & 49 \\
\hline Crassulaceae & 4 & 32 & 5 & 1 & 0 & 42 \\
\hline Primulaceae & 2 & 32 & 0 & 2 & 0 & 36 \\
\hline Scrophulariaceae & 4 & 26 & 3 & 1 & 0 & 34 \\
\hline Brassicaceae & 0 & 22 & 1 & 0 & 0 & 23 \\
\hline Campanulaceae & 5 & 15 & 0 & 0 & 0 & 20 \\
\hline Others & 32 & 245 & 14 & 12 & 1 & 299 \\
\hline Total no of species & 91 & 689 & 62 & 35 & 3 & 880 \\
\hline Total no of families & 32 & 65 & 18 & 18 & 3 & 73 \\
\hline
\end{tabular}

frequently represented by the genus Campanula L.. The most common genera among the alien taxa are Sedum L., Saxifraga L., Aster L., Dianthus L., and Geranium L..

According to their area of origin, $36 \%$ of the alien perennial species available on the horticultural market are native to Europe, Eurasia or Euro-Siberia. Approximately $30 \%$ are from Asia and 27\% from the Americas.

The number of species per nursery varied from 41 to 383 , and $44 \%$ of the species were present in only one nursery. Only one non-escaping alien, Liatris spicata (L.) Willd., was available from all 17 nurseries. Bergenia cordifolia (Haw.) Sternb. and Echinacea purpurea (L.) Moench (both non-escaping aliens) were available from 16 nurseries, and the native Ajuga reptans $\mathrm{L}$. was available from 15 nurseries. The mixture in each nursery was quite similar: $10-20 \%$ natives, $60-80 \%$ non-escaping aliens, $10 \%$ casuals, $2-10 \%$ naturalised. Eight nurseries offered invasive species. The largest and most variable category was non-escaping alien species (Figure 1).

The results show that approximately $70 \%$ of the species had no cultivars or only one type available for sale. Only $43(4.9 \%)$ of the species had ten or more cultivars per species. The outstanding favourite species was the non-escaping alien Hemerocallis hybrida hort. with 134 different varieties, followed by Sempervivum $x$ hybridum hort. (68), Phlox paniculata L. (65), and the naturalised alien Iris germanica L. (42).

\section{Market characteristics and species invasiveness}

The results show that two groups - native and alien species found outside cultivation of any status from casual to invasive - have a similar market profile, in contrast to nonescaping alien species. Alien species that are able to escape and reach certain invasive 


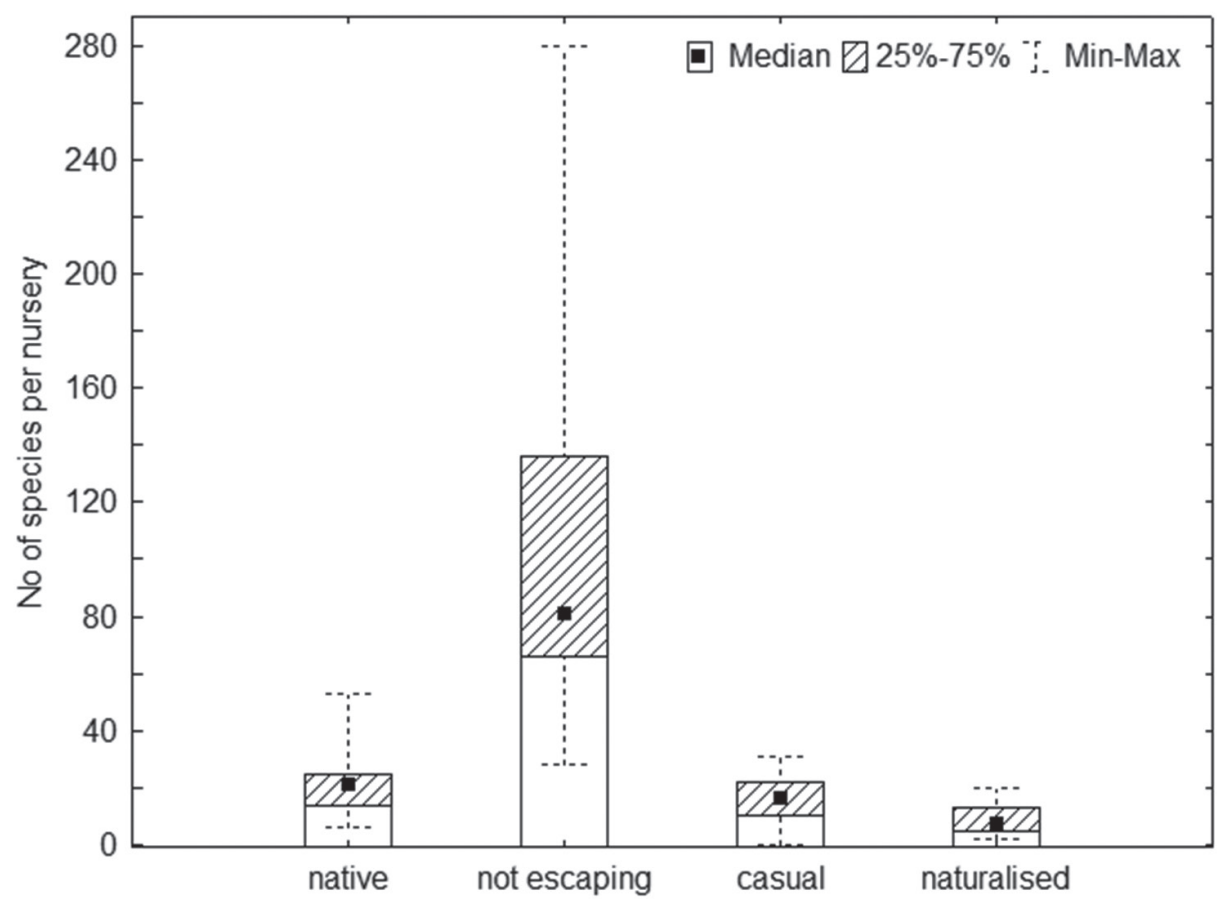

Figure I. The number of species per nursery $(N=17)$ according to species status in Estonia. The results are presented in terms of the extreme values of the data and the median. In addition, three invasive species are offered in catalogues of eight different nurseries.

status in Estonia, are today less expensive $(H=13.9, D F=2, N=668, p=0.001$; Figure 2) and also more widely available $(H=32.6, D F=2, N=880, p<0.0001$; Figure $3)$ than those that have not escaped. In all, the price range of the species is lower when it is widely available and vice versa $(R=-0.36, p<0.05)$. Also, native and escaping alien species have more developed cultivars per species available on the market $(H=13.26$, $D F=2, N=880, p=0.001)$. The latter is also positively correlated to number of nurseries where the species is available $(R=0.66, p<0.05)$. In addition, when a species has already reached a certain invasive status in the alien flora, then the price $(H=0.02, D F$ $=2, N=86, p=0.7)$, availability $(H=0.64, D F=2, N=100, p=0.7)$ and a number of cultivars per species $(H=2.52, D F=2, N=100, p=0.28$ ) does not differ between groups of casual, naturalised and invasive aliens.

Among the already escaped alien species, the abundance $(H=12.3, D F=3, N=$ $83, p=0.007$; Figure 4a) and invasive status of species $(H=10.4, D F=2, N=86, p$ $=0.006$; Figure $4 \mathrm{~b}$ ) tends to increase with residence time. Invasiveness in the whole region (see Table 1 ) is also significantly correlated to the year of introduction into Estonia $(R=-0.33, p<0.05)$, to the species status in Estonia $(R=0.52, p<0.05)$ and to the abundance in the wild $(R=-0.47, p<0.05)$. The supply and demand factors, i.e. today's availability $(R=0.02, p>0.05)$ and price range of alien species in Estonian alien flora $(R=0.08, p>0.05)$, is not correlated with introduction time. 


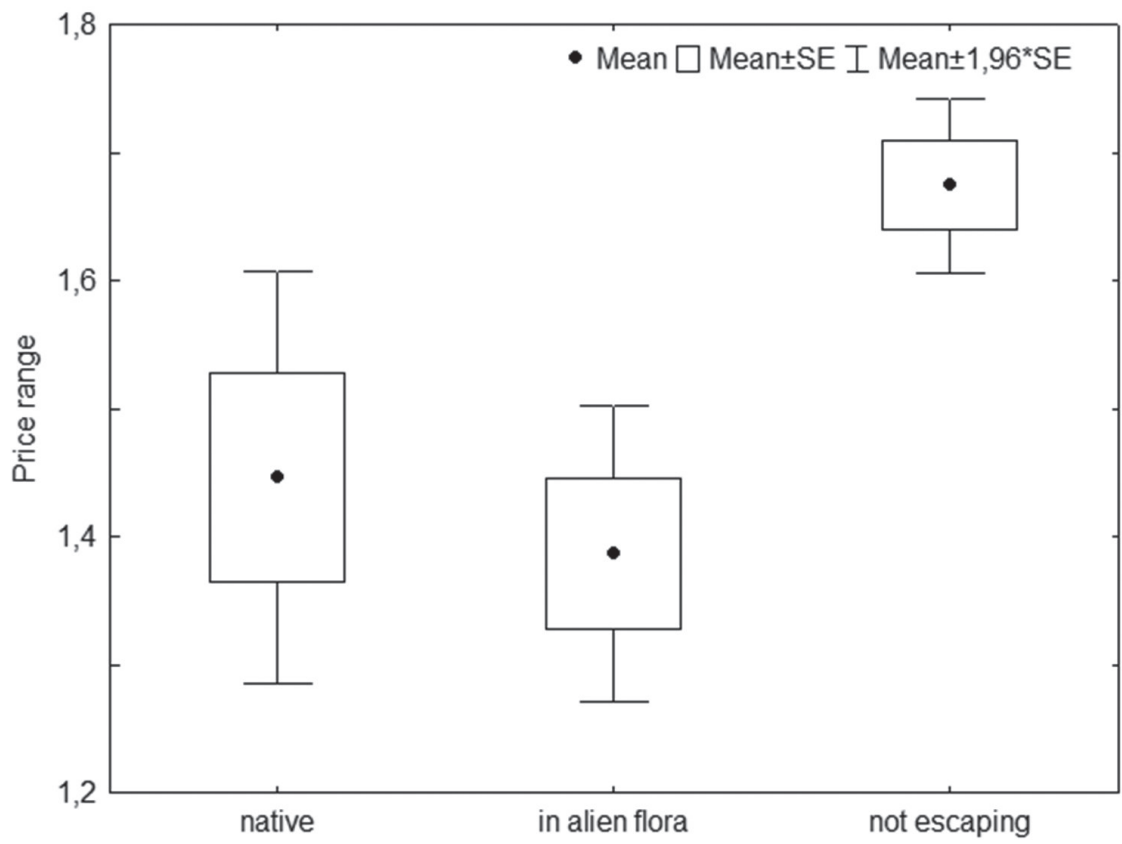

Figure 2. The relationship between species price and status in 17 nurseries in Estonia. Non- escaping aliens were more expensive than natives $\left(z^{\prime}=2.7, p<0.05\right)$ and species in certain status (casual, naturalised, invasive) in alien flora $\left(z^{\prime}=2.8, p=0.02\right)$.

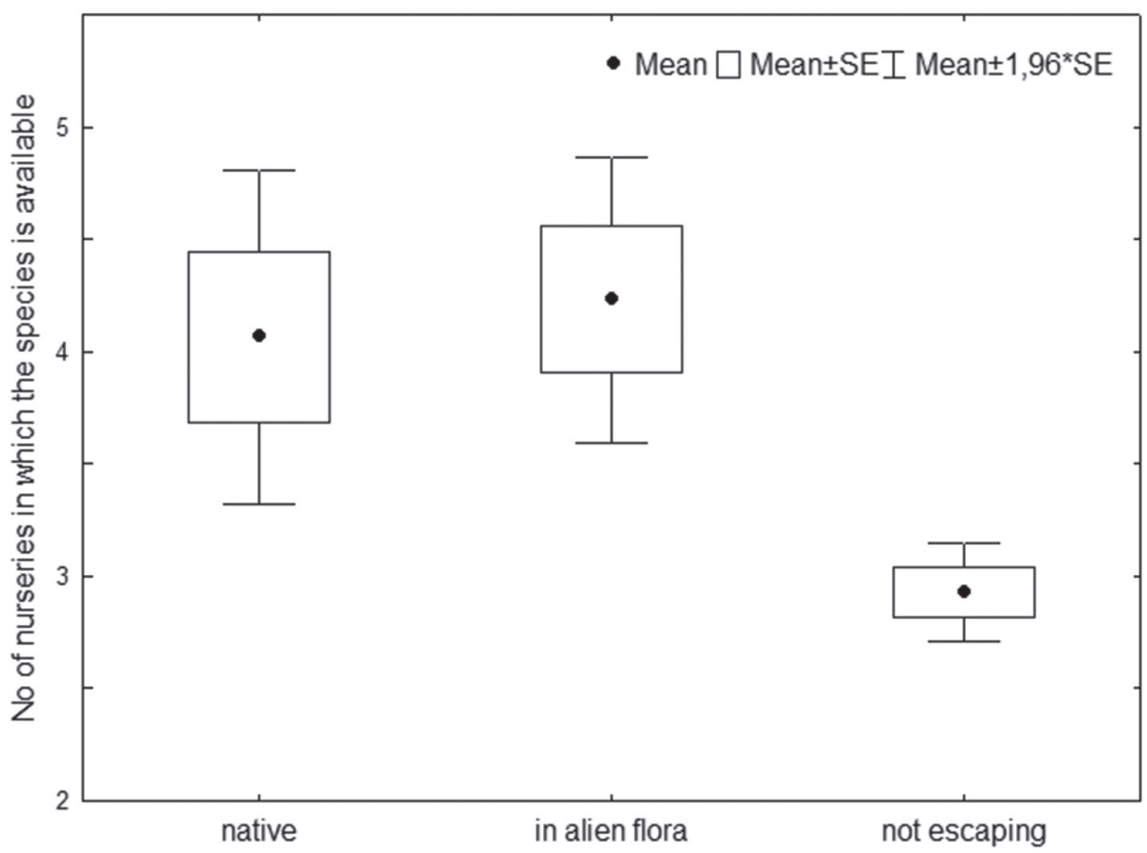

Figure 3. The relationship between species status and availability in 17 nurseries in Estonia. Non-escaping alien species were different from natives $\left(z^{\prime}=4.9, p=0.007\right)$ and aliens in spontaneous flora $\left(z^{\prime}=3.03, p<0.0001\right)$. 
A)

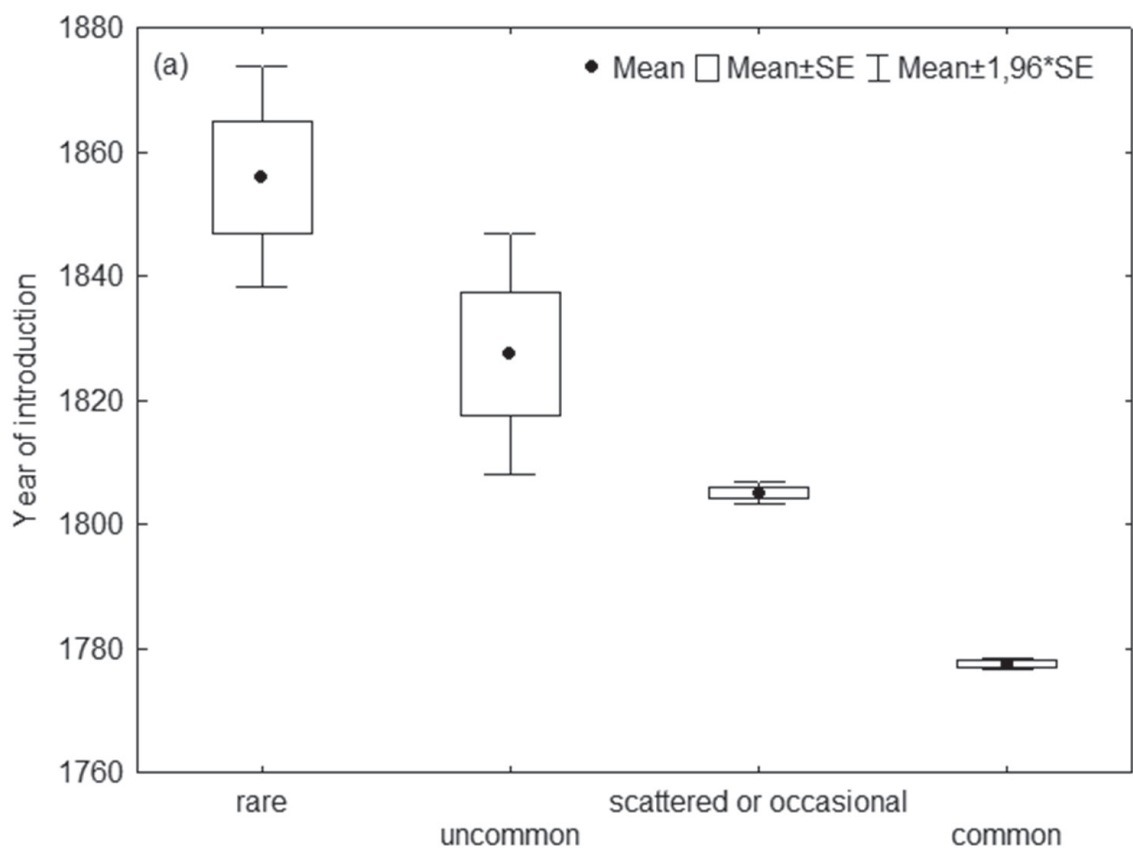

B)

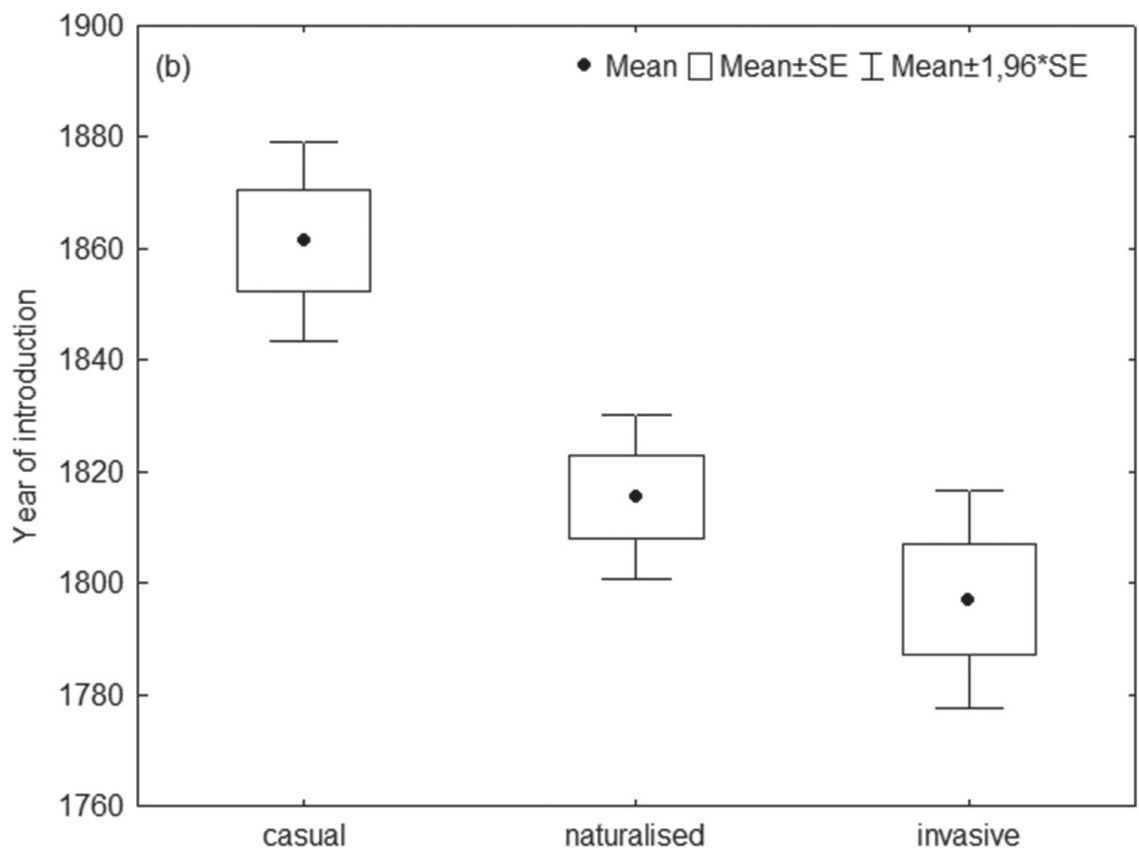

Figure 4. The relationship between alien species characteristics and residence time in 17 nurseries in Estonia: $(\mathbf{A})$ species abundance in the wild and residence time (general test was statistically significant (see text), but no significant differences between groups were detected because of small sample sizes), (B) alien species status and residence time. The residence time of casuals were shorter than of naturalised species $\left(z^{\prime}\right.$ $=3.72, p=0.0006)$. Sample of invasive species was too small to drive statistically significant conclusions. 
Table 3. Estonian commercial nurseries offering herbaceous perennial species, which need national attention as invasive or potentially invasive aliens. Category I: invasive or naturalised species in Estonia and invasive or potentially invasive in at least three neighbouring countries. Category II: naturalised in Estonia and invasive or potentially invasive in two neighbouring countries. Category III: naturalised in Estonia.

\begin{tabular}{|c|c|c|}
\hline Species in category $I$ & Species in category II & Species in category III \\
\hline Lupinus polyphyllus Lindl. & Aster novi-belgii $\mathrm{L}$. & Aquilegia vulgaris $\mathrm{L}$. \\
\hline Solidago canadensis L. $\dagger$ & Euphorbia cyparissias L. & Astrantia major $\mathrm{L}$. \\
\hline Saponaria officinalis $\mathrm{L}$. & Inula helenium $\mathrm{L}$. & Cymbalaria muralis P. Gaertn. et al. \\
\hline $\begin{array}{c}\text { Fallopia japonica (Houtt.) } \\
\text { Ronse Dec. } \dagger\end{array}$ & Sedum spurium M.Bieb. & Delphinium elatum L. \\
\hline $\begin{array}{c}\text { Fallopia sachalinensis (F.Schmidt) } \\
\text { Ronse Decr. } \dagger\end{array}$ & Aconitum napellus L. & Dipsacus fullonum L. \\
\hline Echinops sphaerocephalus L. & Aruncus dioicus (Walter) Fernald & Doronicum pardalianches L. \\
\hline Telekia speciosa (Schreb.) Baumg. & Bellis perennis L. & Echinops ritro L. \\
\hline \multirow[t]{9}{*}{ Vinca minor $\mathrm{L}$. } & Dianthus barbatus L. & Iris germanica $\mathrm{L}$. \\
\hline & Fragaria $x$ ananassa Duchesne & Mentha spicata L. \\
\hline & Lychnis chalcedonica $\mathrm{L}$. & Nepeta cataria $\mathrm{L}$. \\
\hline & Malva alcea $\mathrm{L}$. & Ornithogalum umbellatum $\mathrm{L}$. \\
\hline & Rudbekia laciniata L. & Physalis alkekengi $\mathrm{L}$. \\
\hline & Salvia verticillata $\mathrm{L}$. & Primula elatior $(\mathrm{L}$.$) Hill$ \\
\hline & Viola odorata $\mathrm{L}$. & Primula vulgaris Huds. \\
\hline & & Sanguisorba minor Scop. \\
\hline & & Sisyrinchium angustifolium Mill. \\
\hline
\end{tabular}

$\uparrow$ Species are on The List of Invasive Alien Species (Regulation of the Estonian Minister of Environment No 34, 14 May 2007) - importing live specimens and all transactions with live specimens are prohibited, as stated in The Nature Conservation Act.

\section{List of species needing attention}

As a practical application, a qualitative list of the nationally problematic species among the herbaceous perennials in horticultural catalogues was compiled (Table 3). In Estonia, The Nature Conservation Act forbids the release of alien species into the wild. This Act has resulted in the definition of The List of Invasive Alien Species. For all these species, the import of live specimens and all transactions with live plants are prohibited. As a result, three species are on both the compiled list and the legally defined list.

\section{Discussion}

It is generally accepted that only a limited fraction of introduced species in a given area become naturalised and an even smaller number eventually cause problems (Williamson and Fitter 1996, see also Jeschke et al. 2012). However, initially it is not usually possible to speculate about the potential magnitude of these introductions. The results of the present study demonstrate that the total introduced number of 789 alien herba- 
ceous perennial species available in Estonian commercial nurseries compares with the 787 alien species in the entire Estonian Alien Flora (Ööpik et al. 2008). Species chosen for their ornamental attraction do not necessarily have more invasive potential than other comparable plants, but the proportionally large number of all introduced species increases the likelihood that a fraction will become naturalised and even invasive (see also Mack 2003). The situation should be therefore monitored carefully.

Invasions have a highly dynamic nature, and many of the most problematic alien species are not recent arrivals, but they reflect historical human activities, a phenomenon termed an invasion debt (Essl et al. 2011). One part of this reflection is species residence time in the given area: the longer the species is present in the area, the more propagules are spread and the probability of naturalisation increases (Rejmánek et al. 2005). Unfortunately, in real-life situations the actual introduction time is usually unknown or not determined and for this study were available only years of introduction for alien species in alien flora (Ööpik et al. 2008). Nevertheless, the data in the present paper support the generalisation that the residence time affects the range and frequency, as well as the invasive status, of alien species, at least in cases where the species have already reached a status in spontaneous flora. Also, quite often the most effective predictors of invasiveness were "invasive elsewhere" (Herron et al. 2007). Our data show that the invasive status in Estonia, abundance in the wild and of course, the year of introduction into Estonia correlates with current invasiveness of the species in the whole region. Thus, the regional cooperation in this field should be favoured.

Recently, it has been shown that residence time is a pivotal factor in the spatial patterns of alien species and human pressure has a greater influence on species that have been introduced more recently (Dainese and Poldini 2012). For the future studies we hypothesise here that exponential growth of trade and travel and various pressures from current consumption could decrease the importance of residence time; further, naturalisations and even invasions will take place quicker and be more dependent on other human-mediations than at present.

Propagule pressure created by the historic factors of supply and demand is also an important part of the explanation for the invasiveness of ornamental species (DehnenSchmutz et al. 2007b, Pemberton and Liu 2009). Hence, the current lists have the present levels of socio-economic activity as a background and suggest the possibility of future invasions. Nevertheless, according to the study data, native and expanding wild alien species have today a similar market profile, as they are both inexpensive and widely available. This could be a robust reflection from the previous planting history of alien species, because today's price or availability does not differ between groups of casual, naturalised or invasive aliens. Also, among species in alien flora the introduction time does not predict today's lower price or wider availability. All the species which have currently reached status in spontaneous flora are similarly favoured on the market as "easy-to-grow" species. Such plants are often popular, because they may be readily propagated, and hence are usually less expensive. However, a history of active planting and repeated introductions creates additional pressure and may result in rapid rates of spread, successful escape of species from cultivation and subsequent naturalisation. 
The objective of breeding plants to encourage specific traits differs between agriculture and ornamental horticulture. Obviously, bred ornamental cultivars are genetically distinct from the wild genotype of the species, but usually the change in genetic composition is minor and has little to do with the traits that lead species to become naturalised and invasive (Reichard 2011). Nevertheless, for a few species, recent molecular evidence suggests that continuing propagule pressure aids the spreading of an invasion by introducing genetic variation adaptive for new areas and habitats (Simberloff 2009). In this paper, selection strategies to reduce the invasive potential in introduced plants (Anderson et al. 2006) are not considered. Instead, it is suggested that the number of cultivars per species is likely to be strongly correlated with the number of nurseries where that species is available and will provide an additional opportunity to escape from cultivation. In this case there is another dimension of generated human-mediated propagule pressure. When more cultivars come on the market, then inevitably there will be more specimens in more sites to act as potential dispersers, which is the classical explanation of propagule pressure (Simberloff 2009).

The financial costs to countries of controlling the major invasive species are very high and pose serious problems (Pimentel et al. 2005); hence, regulations are needed. In theory, the control of international release should be straightforward. However, such control is practically difficult due to the financial pressure resulting from the modern global trade in plants. In general, an appropriate framework should enable the trends to be monitored and accept the control of future introductions (e.g., Hulme et al. 2008). There are also difficulties with the negotiation of international agreements. Such difficulties occur within the European Union and are even more pronounced on a global scale.

The one pro-active possibility is that green lists should be compiled. These lists would be especially useful in large-scale projects and would not contradict any trade agreements (Dehnen-Schmutz 2011). In Estonia, The Nature Conservation Act forbids the release of alien species into the wild and The List of Invasive Alien Species prohibits the import of specimens and all transactions with live plants. Currently this list includes 13 plant species, which differ significantly - some species are well-established and some are not yet introduced into Estonia, but have caused problems in countries with similar environments. Unfortunately, the results of this paper show that the compiled list of more problematic species in Estonia and in neighbouring countries include altogether 38 species (Table 3 ). Three regionally problematic species, Solidago canadensis, Fallopia japonica, Fallopia sachalinensis, are available on the Estonian market and are at the same time on the legally prohibited list. Thus, even though the country has quite strict existing regulations, they are not entirely enforced; currently Estonia is only beginning systematic work in this field. It has been proposed that voluntarily implemented Codes of Conduct (Heywood and Brunel 2006) which are addressed to governments, to the horticultural industry and trade, to local environment and conservation agencies, societies and associations, botanic gardens, etc., can be better alternatives to regulate this situation comprehensively. At a national level, a few European countries have addressed the issues of invasive alien species and horticulture and developed a strategy (see references in Heywood and Brunel 2011, p. 19-20). 
Why should the horticultural industry care about alien species? This question arises because the problems caused by alien species do not have a substantial impact on the industry. For this reason, it is probable that further regulation will be difficult. An economical study by Knowler and Barbier (2005) has suggested the possibility of employing market-based instruments consistent with the concept of 'introducers-pay', to regulate the nursery industry. Yokomizo et al. (2012) proposed a cost-benefit analysis for determining plant introduction that incorporates probability to escape, expected economic cost after escape, expected commercial benefits, and the efficiency and cost of containment. Details of the structural changes required, are given by Dehnen-Schmutz et al. (2010), who also emphasise the complexity of the situation. Drew et al. (2010) and Peters et al. (2006) have both suggested that the involvement of consumers and also professionals, as well as education, may yield better results by addressing the moral problem of the risks caused by alien species and understanding the characteristics of the industry. Different voluntary initiatives and regulations are often quite effective and should be increased to limit horticultural introductions of invasive plants (Burt et al. 2007, Niemiera and Von Holle 2009). Some results suggested that merely labelling the plants as invasive or native could be a viable strategy for changes in customer behaviour (Yue et al. 2011). Control measures should at least be part of any overall framework, if there is agreement to implement regulations. However, in nature as in economics, there are always cost-benefit trade-offs.

\section{Conclusions}

1) The availability of plants from the horticultural trade is a major source of alien species, including locally and regionally naturalised and invasive plants.

2) Supply and demand factors create new and reflect previous propagule pressure and are an important component of the reasons behind the invasiveness of ornamental species. In general, native and expanding wild alien species have a very similar profile on the market - both are inexpensive and widely available, and more cultivars per species are also available.

3) There are urgent requirements for regional and national authorities to regulate and control the ornamental plant trade in order to diminish the risk of new invasions.

4) It would be helpful to involve the public in finding alternatives and encouraging best practices for both horticultural professionals and amateurs.

\section{Acknowledgements}

The authors are grateful to the many nursery professionals contacted during this study for their help with the acquisition of the data and to Freda Bunce, Marguerite Oetjen and Simon Bell for improving the English of the paper. Ingolf Kühn provided useful comments on a draft of the manuscript, and feedback from two anonymous reviewers significantly improved this work. 


\section{References}

Anderson NO, Galatowitsch SM, Gomez N (2006) Selection strategies to reduce invasive potential in introduced plants. Euphytica 148: 203-216. doi: 10.1007/s10681-006-5951-7

Barbier EB, Gwatipedza J, Knowler D, Reichard S (2011) The North American horticultural industry and the risk of plant invasion. Agricultural Economics 42: 113-129. doi: 10.1111/j.1574-0862.2011.00556.x

Beans CM, Kilkenny FF, Galloway LF (2012) Climate suitability and human influences combined explain the range expansion of an invasive horticultural plant. Biological Invasions: 14: 2067-2078. doi: 10.1007/s10530-012-0214-0

Bucharova A, van Kleunen M (2009) Introduction history and species characteristics partly explain naturalization success of North American woody species in Europe. Journal of Ecology 97: 230-238. doi: 10.1111/j.1365-2745.2008.01469.x

Burt JW, Muir AA, Piovia-Scott J, Veblen KE, Chang AL, Grossman JD, Weiskel HW (2007) Preventing horticultural introductions of invasive plants: potential efficacy of voluntary initiatives. Biological Invasions 9: 909-923. doi: 10.1007/s10530-007-9090-4

Chrobock T, Kempel A, Fischer M, van Kleunen M (2011) Introduction bias: Ciltivated alien plant species germinate faster and more abundantly than native species in Switzerland. Basic and Applied Ecology 12: 244-250. doi: 10.1016/j.baae.2011.03.001

Dainese M, Poldini L (2012) Does residence time affect responses of alien species richness to environmental and spatial processes? NeoBiota 14: 47-66. doi: 10.3897/neobiota.14.3273

Dehnen-Schmutz K (2011) Determining non-invasiveness in ornamental plants to build green lists. Journal of Applied Ecology 48: 1374-1380. doi: 10.1111/j.13652664.2011.02061.x

Dehnen-Schmutz K, Holdenrieder O, Jeger MJ, Pautasso M (2010) Structural change in the international horticultural industry: Some implications for plant health. Scientia Horticulturae 125: 1-15. doi: 10.1016/j.scienta.2010.02.017

Dehnen-Schmutz K, Touza J, Perrings C, Williamson M (2007a) The horticultural trade and ornamental plant invasions in Britain. Conservation Biology 21: 224-231. doi: 10.1111/j.1523-1739.2006.00538.x

Dehnen-Schmutz K, Touza J, Perrings C, Williamson M (2007b) A century of the ornamental plant trade and its impacts on invasion success. Diversity and Distribution 13: 527-534. doi: 10.1111/j.1472-4642.2007.00359.x

Drew J, Anderson N, Andow D (2010) Conundrums of a complex vector for invasive species control: a detailed examination of the horticultural industry. Biological Invasions 12: 2837-2851. doi: 10.1007/s10530-010-9689-8

Environmental Information (2012) www.keskkonnainfo.ee

Essl F, Dullinger S, Rabitsch W, Hulme PE, Hülber K, Jarošik V, Kleinbauer I, Krausmann F, Kühn I, Nentwig W, Vilà M, Genovesi P, Gherardi F, Desprez-Loustau M-L, Roques A, Pyšek P (2011) Socioeconomic Legacy yields an invasion debt. PNAS 108 (1): 203-207. doi: $10.1073 /$ pnas. 1011728108

Estonian Information System's Authority (2012) http://www.ria.ee/en/ 
European Commission (2011) A comparative assessment of existing policies on invasive species in the EU Member States and in selected OECD countries. Bio Intelligence Service: $86-98$.

Hanspach J, Kühn I, Pyšek P, Boos E, Klotz S (2008) Correlates of naturalization and occupancy of introduced ornamentals in Germany. Perspectives in Plant Ecology, Evolution and Systematics 10: 241-250. doi: 10.1016/j.ppees.2008.05.001

Herron PM, Martine CT, Latimer AM, Leicht-Young SA (2007) Invasive plants and their ecological strategies: prediction and explanation of woody plant invasion in New England. Diversity and Distributions 13: 633-644. doi: 10.1111/j.1472-4642.2007.00381.x

Heywood V, Brunel S (2011) Code of Conduct on Horticulture and Invasive Alien Plants. Nature and environment 162. Council of Europe Publishing, Strasbourg.

Hulme PE (2009) Trade, transport and trouble: managing invasive species pathways in an era of globalization. Journal of Applied Ecology 46: 10-18. doi: 10.1111/j.13652664.2008.01600.x

Hulme PE, Bacher S, Kenis M, Klotz S, Kühn I, Minchin D, Nentwig W, Olenin S, Panov V, Pergl J, Pyšek P, Poques A, Sol D, Solarz W, Vilà M (2008) Grasping at the routes of biological invasions: a framework for integrating pathways into policy. Journal of Applied Ecology 45: 403-414. doi: 10.1111/j.1365-2664.2007.01442.x

Jeschke JM, Gómez Aparicio L, Haider S, Heger T, Lortie CJ, Pyšek P, Strayer DL (2012) Support for major hypotheses in invasion biology is uneven and declining. NeoBiota 14: 1-20. doi: 10.3897/neobiota.14.3435

Niemiera AX, Von Holle B (2009) Invasive Plant Species and the Ornamental Horticulture Industry. In: Inderjit (Ed) Management of Invasive Weeds.

Knowler D, Barbier E (2005) Importing exotic plants and the risk of invasion: are market-based instruments adequate? Ecological Economics 52: 341-354. doi: 10.1016/j. ecolecon.2004.06.019

Kowarik I (2003) Human agency in biological invasions: secondary releases foster naturalisation and population expansion of alien plant species. Biological Invasions 5: 293-312. doi: 10.1023/B:BINV.0000005574.15074.66

Kukk T (1999) Vascular plant flora of Estonia. Teaduste Akadeemia Kirjastus, Tartu-Tallinn. [In Estonian with English summary]

Küster EC, Kühn I, Bruelheide H, Klotz S (2008) Trait interactions help explain plant invasion success in the German flora. Journal of Ecology 96: 860-868. doi: 10.1111/j.13652745.2008.01406.x

Lockwood JL, Cassey P, Blackburn TM (2009) The more you introduce the more you get: the role of colonization pressure and propagule pressure in invasion ecology. Diversity and Distribution 15: 904-910. doi: 10.1111/j.1472-4642.2009.00594.x

Mack RN (2000) Cultivation fosters plant naturalization by reducing environmental stochasticity. Biological Invasions 2: 111-122. doi: 10.1023/A:1010088422771

Mack RN (2003) Global plant dispersal, naturalization, and invasion: pathways, modes, and circumstances. In: Ruiz GM, Carlton JT (Eds) Invasive species: vectors and management strategies, pp. 3-30. Island Press, Washington. 
Mack RN, Erneberg M (2002) The United States Naturalized Flora: Largely the Product of Deliberate Introductions. Annals of the Missouri Botanical Garden 89(2): 176-189. URL: http://www.jstor.org/stable/3298562

Mack RN, Lonsdale WM (2001) Humans as global plant dispersers: getting more than we bargained for. BioScience 51: 95-102. doi: 10.1641/0006-3568(2001)051[0095:HAGPDG]2.0.CO;2

Marco A, Lavergne S, Dutoit T, Bertaudiere-Montes V (2010) From the backyard to the backcountry: how ecological and biological traits explain the escape of garden plants into Mediterranean old fields. Biological Invasions 12: 761-779. doi: 10.1007/s10530-009-9479-3

Milbau A, Stout JC (2008) Factors Associated with Alien Plants Transitioning from Casual, to Naturalized, to Invasive. Conservation Biology 22: 308-317. doi: 10.1111/j.15231739.2007.00877.x

NOBANIS, European Network of Invasive Alien Species. www.nobanis.org

Ööpik M, Kukk T, Kull K, Kull T (2008) The importance of human mediation in species establishment: analysis of alien flora of Estonia. Boreal Environment Research 13(A): 53-67.

Pemberton RW, Liu H (2009) Marketing time predicts naturalization of horticultural plants. Ecology 90: 69-80. doi: 10.1890/07-1516.1

Peters WL, Hockenberry Mayer M, Andreson NO (2006) Minnesota horticultural industry survey on invasive plants. Euphytica 148: 75-86. doi: 10.1007/s10681-006-5942-8

Pimentel D, Zuniga R, Morrison D (2005) Update on the environmental and economic costs associated with alien species in the United States. Ecological Economics 52: 273-288. doi: 10.1016/j.ecolecon.2004.10.002

Pyšek P, Jarošík V, Hulme PE, Kühn I, Wild J, Arianoutsou M, Bacher S, Chiron F, Didžiulis V, Essl F, Genovesi P, Gherardi F, Hejda M, Kark S, Lambdon PW, Desprez-Loustau M-L, Nentwig W, Pergl J, Poboljšaj K, Rabitsch W, Roques A, Roy DB, Shirley S, Solarz W, Vilà M, Winter M (2010) Disentangling the role of environmental and human pressures on biological invasions across Europe. PNAS 107: 12157-12162. doi: 10.1073/ pnas. 1002314107

Pyšek P, Jarošík V, Pergl J (2011) Alien Plants Introduced by Different Pathways Differ in Invasion Success: Unintentional Introductions as a Threat to Natural Areas. PLoS ONE 6(9): e24890. doi: 10.1371/journal.pone.0024890

Pyšek P, Richardson DM (2007) Traits associated with invasiveness in alien plants: where do we stand? In: Nentwig W (Ed) Biological Invasion. Springer, Berlin, 97-125. doi: 10.1007/978-3-540-36920-2_7

Pyšek P, Richardson DM, Rejmánek M, Webster GL, Williamson M, Kirschner J (2004) Alien plants in checklists and floras: towards better communication between taxonomists and ecologists. Taxon 53(1): 131-143. doi: 10.2307/4135498

Reichard SH, White P (2001) Horticulture as a pathway of invasive plant introductions in the United States. BioScience 51: 103-113. doi: 10.1641/0006-3568(2001)051[0103:HAA POI]2.0.CO;2

Reichard S (2011) Horticulture. In: Simberloff D and Rejmanek M (Eds) Encyclopedia of Biological Invasions. University of California Press, 336-342. 
Rejmánek M, Richardson DM, Pyšek P (2005) Plant invasions and invasibility of plant communities. In: van der Maarel E (Ed.) Vegetation ecology. Blackwell Publishing, Cornwall, UK, pp.

Richardson DM, Pyšek P (2012) Naturalization of introduced plants: ecological drivers of biogeographical patterns. New Phytologist 196: 383-396. doi: 10.1111/j.14698137.2012.04292.x

Richardson DM, Pyšek P, Rejmánek M, Barbour MG, Panetta FD, West CJ (2000) Naturalization and invasion of alien plants: concepts and definitions. Diversity and Distributions 6: 93-107. doi: 10.1046/j.1472-4642.2000.00083.x

Siegel S, Castellan NJ (1988) Nonparametric statistics for the behavioral sciences (2nd ed.) New York: McGraw-Hill.

Simberloff D (2009) The role of propagule pressure in biological invasions. Annual Review of Ecology, Evolution, and Systematics: 40: 142-149. doi: 10.1146/annurev.ecolsys. 110308.120304

Smith RM, Thompson K, Hodgson JG, Warren PH, Gaston KJ (2006) Urban domestic gardens (IX): Composition and richness of the vascular plant flora, and implications for native biodiversity. Biological Conservation 129: 312-322. doi: 10.1016/j.biocon.2005.10.045

Starfinger U, Kowarik I, Rode M, Schepker H (2003) From desirable ornamental plant to pest to accepted addition to the flora? - the perception of an alien tree species through the centuries. Biological Invasions 5: 323-335. doi: 10.1023/B:BINV.0000005573.14800.07

Statistics Estonia (2012) http://www.stat.ee/

StatSoft, Inc (2012) STATISTICA (data analysis software system), version 11. www.statsoft.com The List of Invasive Alien Species, Annex of The State Gazette 2004, 134, 2076. https://www. riigiteataja.ee/akt/12828512 [In Estonian]

The Nature Conservation Act, The State Gazette I, 2004, 38, 258. https:/www.riigiteataja.ee/ akt/12808270 [In Estonian]

Thuiller W, Richardson DM, Rouget M, Proches S, Wilson J (2006) Interaction between environment, species traits, and human uses describe patterns of plant invasions. Ecology 87: 1755-1769. doi: 10.1890/0012-9658(2006)87[1755:IBESTA]2.0.CO;2

Trueman M, Atkinson R, Guézou A, Wurm P (2010) Residence time and human-mediated propagule pressure at work in the alien flora of Galapagos. Biological Invasions 12: 39493960. doi: 10.1007/s10530-010-9822-8

Weber E (2003) Invasive plant species of the world: a reference guide to environmental weeds. CABI Publishing.

Williamson M, Fitter A (1996) The varying success of invaders. Ecology 77: 1661-1666. http://www.jstor.org/stable/2265769

Yokomizo H, Possingham HP, Hulme PE, Grice AC, Buckley YM (2012) Cost-benefit analysis for intentional plant introductions under uncertainty. Biological Invasions 14: 839-849. doi: 10.1007/s10530-011-0120-x

Yue C, Terrance MH, Anderson N (2011) Do native and invasive labels affect consumer willingness to pay for plants? Evidence from experimental auctions. Agricultural Economics 42: 195-205. doi: 10.1111/j.1574-0862.2010.00510.x 